\title{
Hizmet Sektörüne Yönelik Tüketici Sinizmi: Demografik Özellikler Açısından Bir Araştırma
}

\begin{abstract}
Gamze Akcay $^{\mathrm{a}}$, Erkan Ozdemir ${ }^{\mathrm{b}}$
Öz: Tüketici sinizmi, işletmelerin kötü niyetli olduğuna ilişkin genel bir inancı yansıtmaktadır. Bu inanç doğrultusunda sinik tüketiciler, işletmelere karşı olumsuz duygular beslemekte ve sinizmin şiddeti arttıkça işletmeler açısından oldukça zararlı davranışlar sergilemeye başlamaktadırlar. ilgili literatür incelendiğinde, tüketici sinizmine ilişkin çalışmaların kısıtlı olduğu ve mevcut çalışmalarda, tüketici sinizminin demografik özellikler açısından yeterince araştırılmadığı görülmektedir. Diğer taraftan, neredeyse hiçbir çalışmada tüketici sinizmi hizmet işletmeleri veya hizmet sektörüne yönelik özel bir tutum olarak ele alınmamıștır. Dolayısıyla bu çalışma, hizmet sektörüne yönelik tüketici sinizminin demografik özelliklere göre farklılı gösterip göstermediğini ortaya koymayı amaçlamaktadır. Bu çalışma, Bursa ilinde yaşayan ve hizmet satın alan / kullanan tüketiciler üzerinde gerçekleştirilmiş ve çalışmada, kolayda örnekleme ve yüz yüze anket yöntemleri kullanılmıştır. Araştırma verileri, bağımsız örneklem t-testi ve tek yönlü varyans analizi (ANOVA) kullanılarak analiz edilmiştir. Analizler sonucunda, hizmet sektörüne yönelik tüketici sinizminin medeni duruma göre anlamlı bir farklıık gösterdiği, cinsiyet, yaş, eğitim durumu ve gelire göre ise anlamlı bir farklıık göstermediği bulunmuştur. Çalışmanın medeni duruma ilişkin bulgusuna göre, hizmet sektörüne yönelik tüketici sinizmi bekâr tüketicilere göre evli tüketicilerde daha fazla görülmektedir.
\end{abstract}

\section{Consumer Cynicism towards The Service Sector: A Study in terms of Demographic Characteristics}

\begin{abstract}
Consumer cynicism reflects a general belief that businesses are malicious. In line with this belief, cynical consumers have negative feelings towards businesses, and as the severity of cynicism increases, they begin to exhibit very harmful behaviors for businesses. When the relevant literature is examined, it is seen that studies on consumer cynicism are limited, and consumer cynicism has not been adequately researched in terms of demographic characteristics in previous studies. On the other hand, almost no studies address consumer cynicism as a specific attitude towards service businesses or the service sector. Therefore, this study aims to reveal whether consumer cynicism towards the service sector differs according to demographic characteristics. This study was carried out on consumers who buy/use services in Bursa, and convenience sampling and face-to-face survey methods were used in the study. The data were analyzed with an independent sample t-test and one-way ANOVA. As a result of the analysis, it was found that consumer cynicism towards the service sector differed significantly according to marital status but did not differ significantly according to gender, age, education level, and income. According to the marital status finding of the study, consumer cynicism towards the service sector is more common among married consumers than single consumers.
\end{abstract}

Anahtar Sözcükler: Sinizm, Tüketici Sinizmi, Demografik Özellikler, Cinsiyet, Medeni Durum, Yaş, Eğitim, Gelir

JEL: M30, M31, M39

$\begin{array}{ll}\begin{array}{l}\text { Geliş } \\ \text { Düzeltme }\end{array} & : \text { : } 02 \text { Haziran } 2021 \\ \text { Kabul } & \text { : 25 Temmuz } 2021 \\ & \text { Tüustos } 2021 \\ \text { Tür } & : \text { Araştırma }\end{array}$

Keywords: Cynicism, Consumer Cynicism, Demographic Characteristics, Gender, Marital Status, Age, Education, Income

JEL: M30, M31, M39

$\begin{array}{ll}\text { Received } & : 02 \text { June } 2021 \\ \text { Revised } & : 19 \text { July } 2021 \\ \text { Accepted } & : 25 \text { August } 2021\end{array}$

Type $\quad$ : Research

a Ph.D., Bursa Uludag University, Institute of Social Sciences, Bursa, Turkiye, gamzeakcay@ hotmail.com (ORCID ID: 0000-00016808-8465)

b Prof., PhD., Bursa Uludag University, Faculty of Economics and Administrative Sciences, Bursa, Turkiye, eozdemir@uludag.edu.tr (ORCID ID: 0000-0003-0903-7638) 


\section{Giriş}

1940 'I yıllardan bu yana, örgütsel davranış (Andersson, 1996; Dean, Brandes ve Dharwadkar, 1998; James, 2005) başta olmak üzere kişilik/psikoloji (Cook ve Medley, 1954; Barefoot, Dodge, Peterson, Dahlstrom ve Williams, 1989), siyaset (Miller, 1974; Pinkleton, Austin ve Fortman, 1998) ve toplum (Kanter ve Mirvis, 1989; Li ve Leung, 2012) bilimleri gibi sosyal bilimler alanlarında araştırılan sinizm konusu araştırma alanı ve bağlamına göre farklı şekillerde tanımlanmıştır. Örneğin kişilik bağlamında sinizm, insanları bencil ve sahtekâr olarak gören, insan doğasına yönelik olumsuz bir görüş veya bakış açısını (Barefoot vd., 1989: 48), toplumsal bağlamda sinizm ise toplum ve topluma ait kurumların iyi niyetli olmadığına ilişkin genel bir inancı yansıtmaktadır (Li ve Leung, 2012: 717). Siyasal bağlamda sinizm, siyasal aktörlerin, siyasal kurumların ve genel olarak siyasal sistemin yetersiz ve ahlâki standartlardan yoksun olduğu inancını içermekte (Dekker ve Meijerink, 2012: 34), örgütsel bağlamda sinizm ise çalışanların istihdam edildiği örgüte ilişkin olumsuz inanç, duygu ve davranışlarını temsil etmektedir (James, 2005: 7). Görüldüğü üzere, sinizm geniş kapsamlı bir yapıdır ve bu açıdan, sinizme ilişkin genel kabul gören bir tanımın varlığından bahsetmek oldukça güçtür.

Sinizm, kişilik araştırmacıları ve psikologlar (Cook ve Medley; 1954; Barefoot vd., 1989; Greenglass ve Julkunen, 1989) tarafından doğuştan gelen bir kişilik özelliği olarak nitelendirilmiştir. Kişilik özelliği temelli yaklaşıma göre, bireyin sinizm düzeyinin değişmesi oldukça güçtür ve bu açıdan, sinizm "kalıcı" bir özellik göstermektedir (Dean vd., 1998: 344). Ancak, sonraki yıllarda sinizm pek çok sosyal bilimci (Kanter ve Mirvis, 1989; Guastello, Rieke, Guastello ve Billings, 1992; Wanous, Reichers ve Austin, 1994; Andersson, 1996; Dekker ve Meijerink, 2012) tarafından, doğuştan gelen bir kişilik özelliğinden ziyade bireyin karşılanmamış beklentileriyle ilişkili olumsuz tecrübelerinden kaynaklanan, tatminsizlik, hayal kırıklığı ve güvensizlikle ilişkilendirilen ve zaman içerisinde değişimi mümkün görülen özel veya genel bir tutum olarak değerlendirilmeye başlamıştır.

Sinizm, ilk kez Helm $(2004,2006)$ tarafından gerçekleştirilen araştırmalarla birlikte "tüketici sinizmi" olarak pazarlama ve tüketici davranışları alanında adından söz ettirmeye başlamıştır. Tüketici sinizminin gelişim sürecini inceleyen ilk araştırmalarda, tüketici sinizminin genellikle tüketicilerin tecrübe ettikleri belirli olaylardan (Helm, 2004, 2006) veya tüketiciler ve işletmeler arasındaki amaç ve değer uyuşmazlıklarından (Chu ve Chylinski, 2006; Chylinski ve Chu, 2010; Gillani, Yousafzai, Pallister ve Yani-De-Soriano, 2011) kaynaklandığı bulunmuştur. Bu açıdan, tüketici sinizmini genellikle tüketicilerin olumsuz tecrübelerine bağı olarak gelişen ve inanç, duygu ve davranış bileşenlerini içeren öğrenilmiş bir tutum olarak değerlendirmek mümkündür. Bir diğer ifadeyle, tüketici sinizmi pazardaki işletmelerin dürüstlükten yoksun veya kendi çıkarları peşinde oldukları inancına dayanan ve olumsuz duygular (öfke, kızgınlık, iğrenme, kin vb.) içeren öğrenilmiş bir tutumdur (Helm, 2006: 37). Konuyla ilgili araştırmalar (Helm, 2006; Chylinski ve Chu, 2010; Helm, Moulard ve Richins, 2015; Akçay ve Özdemir, 2019; Akçay, 2021), sinik tüketicilerin şikâyet (işletmeye veya diğer kurum ve kuruluşlara), olumsuz ağızdan ağıza iletişim, boykot, markayı / işletmeyi terk etme gibi işletmenin imajını zedeleyen ve kısa ve uzun vadede satışları etkileyerek işletmeyi finansal açıdan tehdit eden (Chylinski ve Chu, 2010: 808) kötüleyici ve cezalandırıcı davranışlar sergilediklerini göstermektedir. Bu açıdan, tüketici sinizmi işletmeler tarafından göz ardı edilmemesi gereken oldukça zararlı bir tüketici tutumudur.

Ilgili literatürde, hizmetlerin temel özelliklerinin (soyutluk, heterojenlik vb.) tüketicilerin karar alma süreçlerinde belirsizlik ve risk algılarını arttırarak, tutum ve davranışlarını olumsuz yönde etkilediğini gösteren pek çok araştırma (Garner, 1986; George, Weinberger ve Kelly, 1985; Mitchell ve Greatorex, 1993) bulunmaktadır. Bu açıdan, hizmet sektöründe faaliyet gösteren işletmeler için müşterilerle güvene dayalı ilişkiler kurmak, memnuniyet ve sadakati sağlamak diğer işletmelere göre oldukça güçtür. Sinik tüketicilerin işletmelere yönelik güvensiz ve şüpheci yaklaşımları ve sahip oldukları olumsuz duygular (Chylinski ve Chu, 2010: 799; Helm vd., 2015: 516) hizmetlerin temel özelliklerinin olumsuz yönleriyle birleştiğinde ise tüketici sinizminin, diğer sektörlerde faaliyet gösteren işletmelere göre hizmet işletmeleri için daha büyük bir tehdit oluşturacağı düşünülmektedir. Buradan hareketle, bu çalışmada tüketici sinizmi hizmet sektörüne yönelik olarak araştırılmıştır.

Sinizm literatüründe, sinizmin farklı türleri ile bireylerin demografik özellikleri arasındaki ilişkileri araştıran çalışmalar (Mirvis ve Kanter, 1991; Kalağan ve Güzeller, 2010; Leung, Li ve Zhou, 2012; Durrah, 
Chaudhary ve Gharib, 2019) bulunmakla birlikte, özel bir sinizm türü olan tüketici sinizmini demografik özellikler açısından araştıran çalışmalar (Indibara, 2017; Andaç, 2019) oldukça kısıtıdır. Bu çalışmalarda ise tüketici sinizmi, genel olarak pazara yönelik bir tutum olarak değerlendirilmiş, hizmet sektörü açısından yeterince incelenmemiştir. Buradan hareketle bu çalışma, hizmet sektörüne yönelik tüketici sinizminin tüketicilerin demografik özellikleri açısından farklılık gösterip göstermediğini ortaya koymayı amaçlamaktadır. Çalışmada, tüketici sinizmi cinsiyet ve medeni durum gibi temel demografik özelliklerin yanı sıra yaş, eğitim ve gelir düzeyleri açısından da araştırılmıştır.

Tüketici sinizmine ilişkin Türkiye'de gerçekleştirilen çalışmalar incelendiğinde, tüketici sinizminin araştırmacılar için oldukça yeni bir kavram olması nedeniyle henüz yeterince araştırılmadığı ve mevcut çalışmalarda, tüketici sinizminin sıklıkla demografik özellikler dışındaki faktörler açısından incelendiği görülmektedir. Örneğin ulusal yazında konuyla ilgili ilk çalışmalardan biri olan ve Atılgan vd. (2017) tarafından gerçekleştirilen çalışmada, tüketici sinizmi ile tüketicilerin boykota ilişkin tutumları ve satın alma niyetleri arasındaki ilişkiler araştırıımıştır. Başka bir çalışmada, Akçay ve Özdemir (2019) tarafından tüketici sinizminin kavramsal alt yapısı, gelişimi ve sinik tüketici davranışları teorik olarak incelenmiştir. Bu çalışma ise hizmet sektörüne yönelik tüketici sinizmine odaklanması ve tüketici sinizminin demografik özelliklere göre farklıık gösterip göstermediğini ampirik olarak ortaya koyması açısından yukarıda bahsi geçen çalışmalardan farklıık göstermektedir. Göktaş (2019)'ın çalışmasında, tüketici sinizmi cinsiyet açısından araştırıımış, ancak tüketicilerin diğer demografik özelliklerine odaklanılmamıştır. İlgili çalışmadan farklı olarak bu çalışmada, tüketici sinizmi cinsiyetin yanı sıra medeni durum, yaş, eğitim ve gelir değişkenleri açısından da araştırılmıştır. Andaç (2019) tarafından gerçekleştirilen başka bir çalışmada, tüketici sinizmi cinsiyet, medeni durum, yaş, eğitim ve geliri içeren demografik özellikler açısından araştırılmış ancak ilgili çalışmada, tüketici sinizmi pazara yönelik genel bir tutum olarak ele alınmıştır. İlgili çalışmadan farklı olarak bu çalışmada ise tüketici sinizmi hizmet sektörüne yönelik olarak incelenmiştir. Bu çalışma ile benzer olarak, Akçay (2021) tüketici sinizmini hizmet sektörü açısından incelemiş ancak ilgili çalışmada, tüketici sinizminin öncülleri ve sonuçlarına odaklanılarak tüketici sinizmi demografik özellikler açısından incelenmemiştir. Görüldüğü üzere, bu çalışma tüketici sinizmini hizmet sektörüne yönelik özel bir tutum olarak ele alması ve tüketici sinizmini demografik özellikler açısından araştırması açısından Türkiye'de gerçekleştirilen çalışmalardan farklııık göstermektedir. Dolayısıyla bu çalışmanın, yukarıda bahsi geçen yönlerden sahip olduğu farklılıklar nedeniyle özellikle ulusal alan yazına önemli katkılar sağlayacağı düşünülmektedir. Diğer taraftan, tüketicilerin demografik özelliklerini dikkate alarak sinik tutumun gelişimini önlemek ve mevcut sinizmi etkin bir şekilde yönetebilmek açısından bu çalışmanın hizmet işletmelerine oldukça faydalı olabileceğini ifade etmek de mümkündür.

Bu çalışmada öncelikle, sinizm ve tüketici sinizmine ilişkin kavramsal çerçeve sunulmuştur. Daha sonra literatür araştırması yapılarak, tüketici sinizmi ile tüketicilerin demografik özellikleri arasındaki ilişkiler incelenmiş ve buradan hareketle oluşturulan araştırma hipotezlerine yer verilmiştir. Sonrasında, araştırmanın yöntem ve bulguları sunulmuştur. Araştırmanın sonuç bölümünde ise elde edilen bulgular değerlendirilmiş, araştırmanın pazarlama literatürüne ve pratiğe yönelik katkıları sunulmuş ve önerilerde bulunulmuştur.

\section{Kavramsal Çerçeve}

\subsection{Sinizm}

Felsefe literatürü incelendiğinde, kökeni Antik döneme kadar uzanan sinizmin bir yaşam biçimi, dünya görüşü veya kural ve normların reddedilmesine dayanan özel bir düşünce / görüş sistemi olarak ortaya çıktığı görülmekte ve toplumsal değerlerin yarattığı hayal kırıklığından kaynaklandığı öne sürülmektedir (Kudriavtseva ve Tsiplakova, 2017: 918). Antisthenes, Diogenes ve Krates ilk sinikler olmakla birlikte, Diogenes sinik felsefenin en önemli temsilcisidir (Luck, 2011: 15). Yaşam biçimleri ve davranışlarının köpekleri andırması nedeniyle Diogenes başta olmak üzere tüm sinikler, diğer insanlar tarafından "köpek" olarak adlandırımışlardır. Zira Diogenes'in sokaklarda veya boş fıçıların içerisinde yaşadığı ve tüm yaşamsal faaliyetlerini halka açık olarak giderdiği öne sürülmektedir. Ancak Diogenes, tüm eleştirilerin aksine "köpek" benzetmesini kendi felsefesi için bir ad olarak benimsemiş ve Yunanca'da köpek anlamına gelen "kyon" kelimesi, "kinik" haline dönüşmüştür. Günümüzde ise "kinik" yerine genellikle "sinik" kelimesi 
kullanılmaktadır (Chaloupka, 1999: 5). Diogenes'in, güneşli havada Atina sokaklarında elinde fenerle gezerek dürüst bir insan aradığı öne sürülmekte (Chaloupka, 1999: 3) ve bu anekdot, sinizmin mantıklı bir argüman yerine yıkıcı bir meydan okuma yoluyla gerçeği arayan bir felsefe olduğu görüşünü desteklemektedir (Higgie, 2014: 186).

Erdemli bir yaşamı amaç edinen sinikler için erdeme ve böylece mutluluğa ulaşmanın tek yolu kanaatkâr bir yaşam biçimini benimsemektir. Erdem, aklın ve doğru düşünmenin bir sonucudur ve lüks yaşam, zenginlik, itibar ve iktidar gibi yaşamsal hazlar aklın otoritesini tehdit ederek bireyi asıl amaçlarından saptırmaktadır. Dolayısıyla sinikler için erdemli bir yaşama, toplumun değer ve normlarına bağlı kalmaksızın kendi kendine yetebilme ve bağımsızlıkla ulaşılabilir (Luck, 2011: 23-24). Bu açıdan sinikler, erdemli bir yaşamı tanımlayan kendi kendine yetebilme ve bağımsızlık adına toplumun değer, norm ve kurumlarını şiddetle reddederek, hareketleri ve sözleriyle aşağılamışlardır (Dean vd., 1998: 342).

Sinizmin temel fikir ve ilkeleri, yüzyıllar içerisinde deformasyona uğramış ve siniklerin yaşam biçimleri ile sinik felsefenin fikir ve ilkeleri arasında uyuşmazlıklar görülmeye başlamıştır (Kudriavtseva ve Tsiplakova, 2017: 919). Sinizm literatürü incelendiğinde, özellikle 18. yüzyılın sonlarında, sinik felsefenin Antik dönemdeki anlamından büyük ölçüde uzaklaştı̆̆ı ve olumsuz bir yapıya bürünmeye başladığı görülmektedir (Mazella, 2007: 182). Günümüzde ise sinizm, etik değer ve ilkelerin gerçekliğini reddeden, doğruluk ve dürüstlük gibi erdemleri sorgulayan ve iyi niyetli söylem ve davranışlara dahi şüpheyle yaklaşan olumsuz bir bakış açısı halini almıştır (Navia, 1996: 1). Sinikler, karşı tarafın kişisel çıkarları peşinde olduğuna inanmakta ve karşı tarafın kendisinden faydalanmaya veya kendisini aldatmaya çalıştığını düşünmektedirler (Hoffmann, Lutz ve Ranzini, 2016: 4). Bir diğer ifadeyle sinikler, diğer bireyleri, toplumu ve / veya kurumları sahtekâr veya bencil olarak görmektedirler (Barefoot vd., 1989: 48).

\subsection{Tüketici Sinizmi}

Tüketici sinizmi, işletmelerin eylemlerinin arkasında kendi çıkarlarına hizmet eden gizli amaç veya niyetleri olduğu inancından hareketle tüketiciler tarafından belirli bir işletmeye (Chylinski ve Chu, 2010) veya pazara (Helm, 2006; Helm vd., 2015) karşı geliştirilen zararlı bir tutumdur. Tüketici sinizmi kavramının pazarlama literatürüne kazandırılmasında önemli katkıları olan Helm (2006: 74)'e göre tüketici sinizmi, işletmeler arasında yaygın bir fırsatçılık olduğu ve bu fırsatçılığın tüketicilere zarar veren bir pazar yarattığı algısıyla karakterize edilen, pazara yönelik istikrarlı ve öğrenilmiş bir tutumdur. Chylinski ve Chu (2010: 799) tüketici sinizmini, tüketicide şüpheyle başlayan, savunma girişimleriyle devam eden ve yabancılaşmayla son bulan bilişsel, davranışsal ve duygusal tepkiler süreci olarak tanımlamışlardır. Mikkonen, Moisander ve Fırat (2011: 101) ise tüketici sinizmini, tüketicide pazara ve pazardaki işletmelere karşı hayal kırıklığı, şüphe ve kandırılmaya çalışıldığını fark etme hissi yaratan ve istikrar gösteren bir telafi stratejisi olarak nitelendirmişlerdir.

Tüketici davranışları literatürü incelendiğinde, "güvensizlik", "şüphecilik" ve "yabancılaşma" gibi sinizmle benzer veya ilişkili yapıların olduğu görülmektedir. Güvensizlik, sinizm gibi bir inançtır. Ancak sinizm, güvensizliğin yanı sıra şüphe, hayal kıııklı̆ı ve ümitsizlik gibi diğer duygusal ve bilişsel bileşenleri de içermekte ve bu açıdan güvensizlikten ayrılmaktadır (Andersson, 1996: 1398; Chylinski ve Chu, 2010: 798-799). Sinizme benzer bir diğer kavram şüpheciliktir. Tüketici sinizmi, şüpheciliğin yanı sıra işletmelerin eylemlerinin arkasındaki güdülere yönelik güvensizlik ve olumsuz duygular içermektedir (Helm, 2004: 348). Diğer taraftan şüpheci tüketiciler kanıtlarla ikna edilmeye istekliyken, sinik tüketiciler ise sabit fikirlidir (Kanter ve Mirvis, 1989: 1) ve kanıtlarla ikna ederek sinik tüketicilerin fikirlerini değiştirmek oldukça güçtür (Mohr, Eroğlu ve Ellen, 1998: 33). Tüketici yabancılaşması ise araştırmacılara (Durand ve Lambert, 1980; Lambert, 1980) göre, güçsüzlük, kültürel yabancılaşma, normsuzluk ve anlamsızık gibi boyutları olan çok boyutlu bir yapıdır. Tüketici yabancılaşması, işletmelerin kendi çıkarları için tüketicilerin menfaatlerini hiçe sayarak etik dışı davranışlar sergilemekten kaçınmayacakları inancını (Durand ve Lambert, 1985: 10) içeren "normsuzluk" boyutu açısından sinizmle benzerlik göstermekte ancak içerdiği diğer boyutlar açısından oldukça geniş kapsamlı bir yapı olup, bu yönüyle sinizmden ayrılmaktadır (Helm, 2006: 489). 
Tüketici sinizmi literatürü incelendiğinde, konuyla ilgili ilk araştırmaların genellikle tüketici sinizminin öncülleri ve sonuçları üzerine odaklandıkları görülmektedir. Örneğin Helm $(2004,2006)$ tarafından, tüketici sinizminin kavramsal alt yapısını oluşturmak ve gelişim sürecini anlamak amacıyla sinik tüketicilerle gerçekleştirilen görüşmelere dayanan araştırmalar sonucunda, tüketicilerin sinik olmalarının nedenini yaşadıkları veya tanıdıkları birinin başından geçen belirli olaylara bağladıkları görülmüştür. Örneğin sinik bir tüketici, 9-10 yaşlarındayken bir arkadaşının çizgi romandaki bir reklam ilanından oyuncaklar sipariş ettiğini ancak gelen oyuncakların plastikten yapılmış ve oldukça basit ürünler olduğunu görerek hayal kırıklı̆ına uğradığını belirtmiştir. İlgili tüketici, arkadaşının başına gelen bu olayın kendi yaşamında bir dönüm noktası olduğunu ve bu olaydan sonra işletmelere karşı güvensiz ve şüpheci hissetmeye başladığını ifade etmiştir. İlgili örnekte görüldüğü üzere, tüketiciler için öğrenme deneyimi niteliği taşıyan bu olaylar, tüketicileri bir genelleme sürecine iterek işletmelerin gelecekteki eylemlerine ilişkin beklentilerini ve pazara yönelik davranışlarını şekillendiren, kişilik özelliği benzeri, öğrenilmiş bir tutuma (sinizm) dönüştürmektedir. Bu olaylar, sinizmin gelişimine katkıda bulunmakta ancak sinizmin varlığı için tek başına yeterli olmamaktadır. (Helm, 2006: 42-43).

Helm (2006) tarafından, tüketici sinizminin tüketicilerin kişilik özellikleri açısından öncülleri ve pazara yönelik davranışları açısından sonuçlarının incelendiği araştırma sonucunda, olumsuz duygulanım ve toplumsal sinizm tüketici sinizminin öncülleri, pazarı şekillendirme (aktivist ve eleştirel davranışlar) ve pazardan geri çekilme (gönüllü sade yaşam tarzları vb.) davranışları ise tüketici sinizminin sonuçları olarak bulunmuştur. Akçay ve Özdemir (2019) tarafından gerçekleştirilen çalışmada, tüketici sinizminin gelişiminde etkili olan faktörler ve sinik tüketici davranışları literatür araştırmasına dayanarak teorik açıdan incelenmiştir. ilgili çalışmaya göre, tüketicilerin yaşadıkları / tanık oldukları kişisel olaylar, olumsuz duygulanım, toplumsal sinizm ve işletmelerin etik olmayan pazarlama uygulamaları gibi faktörler tüketici sinizminin gelişiminde etkili olmakta ve sinik tüketiciler, şikâyet, olumsuz ağızdan ağıza iletişim, boykot, işletmeyi terk etme ve pazardan geri çekilme gibi davranışlar göstermektedirler.

Toplumsal sinizm ile tüketici sinizmi arasındaki ilişkiyi araştıran Indibara ve Varshney (2020), toplumsal sinizmin pazara yönelik tüketici sinizmi ile pozitif yönde ilişkili olduğu bulgusuna ulaşmıştır. Akçay (2021) ise tüketici sinizminin öncüllerini ve sonuçlarını hizmet sektörü açısından incelemiştir. Araştırma sonucunda, toplumsal / kurumsal sinizm ve etik dışı pazarlama uygulamalarının hizmet sektörüne yönelik tüketici sinizmini pozitif yönde etkilediği, hizmet sektörüne yönelik sinik tutumun ise tüketicilerde olumsuz ağızdan ağıza iletişim, işletmeyi boykot etme ve işletmeyi / markayı terk etme davranışlarıyla kendisini gösterdiği bulunmuştur.

Chylinski ve Chu (2010), tüketicilerde sinik tutumun gelişimi ve bir dizi davranışsal tepkiyle ifade edildiğini gösteren iki aşamalı bir model önerisi sunmuşlardır. Modele göre, tüketici sinizminin temelinde "amaç uyuşmazlıkları" ve "değer uyuşmazlıkları" yatmaktadır. İşletmenin eylemleri ile tüketicilerin amaçları ve değerleri arasındaki uyuşmazlıkların tekrarlanması sonucunda, tüketiciler tepki olarak olumsuz ağızdan ağıza iletişim, şikâyet, işletmeyi terk etme, farklı bir işletmeyi tercih etme ve tazminat talebi gibi olumsuz (sinik) davranışlar göstermektedirler. Tahmine dayalı beklentiler, amaç uyuşmazlıkları ile sinik davranışlar arasındaki ilişkide aracı rolü üstlenmektedir. Tahmine dayalı beklentiler (geleceğe yönelik inançlar), tüketicilerin önceki deneyimlerine dayalıdır. Zira önceki deneyimlerden elde edilen ipuçları, tahmine dayalı beklentilere yol açmakta ve tahmine dayalı beklentiler, gelecekteki deneyimin muhtemel başarısına ilişkin bilgi vermektedir. Dolayısıyla tahmine dayalı beklentilerin bilişsel doğası, tüketici amaçlarını sinik davranışlara bağlayabilecek olası bir mekanizma sağlamaktadır. Diğer taraftan, kişisel çıkar atıfları değer uyuşmazlıkları ile sinik davranışlar arasındaki ilişkide aracı rolüne sahiptir. Zira işletmelerin öne sürdükleri nedenlerden farklı eylemler sergilemeleri, tüketicileri işletmelerin eylemlerinin arkasındaki niyeti sorgulamaya itmektedir. Tüketiciler, işletmenin tutarsız eylemlerini işletme çıkarlarına hizmet eden gizli amaç veya niyetlere atfettiklerinde ise kendi çıkarları doğrultusunda hareket etmeye başlayarak sinik davranışlar sergilemektedirler (Chylinski ve Chu, 2010: 799-801). Benzer bir araştırmada, adil ticaret uygulamalarına yönelik tüketici sinizmini araştıran Gillani vd. (2011) ise amaç ve değer uyuşmazlıklarının adil ticaret uygulamalarına yönelik tüketici sinizmi üzerinde etkili olduğu bulgusuna ulaşmışlardır. Ayrıca araştırma sonucunda, adil ticaret uygulamalarına yönelik sinizmin adil ticaret uygulamalarına yönelik güvensizliği pozitif 
yönde, adil ticaret uygulamalarına yönelik güvensizliğin ise tüketicilerin adil ticaret ürünlerini satın alma niyetini negatif yönde etkilediği ve bunun sonucunda, tüketicilerin adil ticaret ürünleri için prim ödemeyi düşünmedikleri bulunmuştur.

Ilgili literatürde, tüketici sinizmine daha olumlu ve radikal bakış açılarıyla yaklaşan çalışmalar da bulunmaktadır. Örneğin Mikkonen vd. (2011), literatürde olumsuz inanç ve duygularla karakterize edilen ve olumsuz bir tutum olarak kabul gören tüketici sinizmini, tüketim toplumunun düzen ve normlarına karşı bir direniş ve toplumsal eleştiri biçimi olarak daha ılımlı bir bakış açısıyla değerlendirilmişlerdir. illgili araştırmada, Noel kutlamalarının pazarlama çılgınlığına dönüşmesinin şiddetle eleştirildiği Noel karşıtı siteler incelenmiş ve tüketicilerin bu eleştirilerinin altında sinik tutumların yattığı bulgusuna ulaşılmıştır. Odou ve Pechpeyrou (2011) ise tüketici sinizminin pazarlama girişimlerine yönelik bir savunma stratejisi olarak nitelendirildiği geleneksel bakış açısıyla birlikte, tüketim ideolojisini sorgulayıcı yönüne de odaklanarak tüketici sinizmine ilişkin savunmacı, saldırgan, yıkıcı ve etik olmak üzere dört farklı yaklaşımı içeren bir sınıflandırma önermişlerdir. Saldırgan ve savunmacı yaklaşımlar, işletmelerin kendi çıkarları peşinde olduklarını düşüncesi ve işletmeler tarafından kandırılmama endişesinde birleşmektedir. Ancak savunmacı sinikler pazarlama tekniklerine karşı psikolojik bir direniş sergilerken, saldırgan sinikler pazarlama tekniklerine benzer manipüle edici taktiklerle işletmeleri sömürme yoluna gitmektedirler. Yıkıcı ve etik yaklaşımlarda ise tüketim ideolojisi sorgulanmakta ve tüketim karşıtlığı ön plana çıkmaktadır. Ancak yıkıcı sinizm söylemsel ve provokatif eylemleri içerirken, etik sinizmde tüketici doğal benliğine ulaşmak amacıyla toplum tarafından dayatılan metalaştırmadan kendisini soyutlamakta ve sade bir yaşamı benimsemektedir.

Tüketici sinizmi araştırmacılarından Indibara (2017), reklamlara yönelik şüpheciliğin tüketici sinizmi üzerindeki etkisini incelemiştir. Araştırma sonucunda, reklam şüpheciliğinin tüketici sinizmi üzerinde pozitif yönde etkili olduğu, reklam şüpheciliği üzerinde ise tüketicilerin kişilik özellikleri pozitif etki gösterirken, yaş ve eğitim düzeyiyle ölçülen tüketim deneyimlerinin benzer bir etkiye sahip olmadığı bulunmuştur. Tüketicilerin boykota yönelik tutumlarını ve satın alma niyetlerini, tüketici sinizmi açısından araştıran Atılgan vd. (2017), tüketici sinizmi ile boykota yönelik tutum arasında pozitif yönde, tüketici sinizmi ile satın alma niyeti arasında ise negatif yönde bir ilişki bulmuşlardır. Ağızdan ağıza pazarlama ile tüketici sinizmi arasındaki ilişkiyi inceleyen Göktaş (2019) ise ağızdan ağıza pazarlama faaliyetlerinin tüketici sinizmi üzerinde oldukça düşük bir etkiye sahip olduğu bulgusuna ulaşmıştır.

\section{Literatür Araştırması ve Araştırma Hipotezleri}

\subsection{Tüketici Sinizmi ve Demografik Özellikler Arasındaki ilişkiler}

Sinizm ile ilgili literatür incelendiğinde, sosyal bilimlerin pek çok alanında sinizm ile bireylerin demografik özellikleri arasındaki ilişkileri araştıran ve farklı sonuçlara ulaşan araştırmaların olduğu görülmektedir. Örneğin Mirvis ve Kanter (1991) tarafından gerçekleştirilen araştırma sonucunda, kadınlara göre erkeklerin ve diğer yaş gruplarına göre 55 yaş ve üzerindeki bireylerin sinizm düzeylerinin daha yüksek olduğu bulunmuştur. Eğitim ve gelir düzeyleri açısından ise bireylerin eğitim ve gelir düzeyleri düştükçe sinizm düzeyinin arttığı bulunmuştur. Öğretmenlerin örgütsel sinizm düzeylerini inceleyen Kalağan ve Güzeller (2010), örgütsel sinizmin biyolojik cinsiyet, medeni durum ve yaş açısından anlamlı bir farklıık göstermediği, mesleki deneyim ve eğitim düzeyi açısından ise anlamlı bir farklılık gösterdiği bulgularına ulaşmışlardır. Buna göre, mesleki deneyimi az olan ve lisansüstü mezunu olan öğretmenlerin örgütsel sinizm düzeyleri diğerlerine göre daha yüksektir. Toplumsal sinizmi araştıran Leung vd. (2012) ise erkeklerin toplumsal sinizm düzeylerinin kadınlardan daha yüksek olduğu bulgusuna ulaşmışlardır.

Chiaburu vd. (2013) tarafından çalışanların örgütsel sinizm düzeylerinin incelendiği araştırma sonucunda, çalışanların demografik özellikleri ile örgütsel sinizm arasında anlamlı bir ilişki bulunmamıştır. Örgütsel sinizmi araştıran Durrah vd. (2019) tarafından gerçekleştirilen araştırma sonucunda, kadın çalışanların örgütsel sinizm düzeylerinin erkek çalışanlardan daha yüksek olduğu, bekâr çalışanların ise evli çalışanlara göre daha sinik oldukları bulunmuştur. Çalışanların yaşları açısından, genç çalışanların yaşlı çalışanlardan daha sinik oldukları, mesleki deneyim açısından ise 5-10 yıl arası mesleki deneyime sahip olan çalışanların sinizm düzeylerinin 5 yıldan daha az ve 10 yıldan daha fazla mesleki deneyime sahip olanlardan 
daha yüksek olduğu bulunmuştur. Kasalak (2019) tarafından öğrencilerin sinizm düzeylerinin incelendiği araştırma sonucunda ise öğrenci sinizminin cinsiyete göre anlamlı bir farklılık gösterdiği ve kadın öğrencilerin erkek öğrencilerden daha sinik oldukları bulunmuştur.

Tüketici sinizmi literatürü incelendiğinde, tüketici sinizminin tüketicilerin demografik özellikleri açısından yeterince araştırılmadığı görülmektedir. Bu durum üzerinde, sinizmin pazarlama alanı için yeni bir konu olması ve pazarlama araştırmacıları tarafından henüz yeterince araştırımamasının etkili olduğu düşünülmektedir. Konuyla ilgili araştırmalardan birinde, Indibara (2017) tüketici sinizmini tüketicilerin demografik özellikleri açısından incelemiş ve tüketici sinizminin cinsiyet, yaş ve eğitim düzeyine göre anlamlı bir farklıık göstermediği bulgusuna ulaşmıştır. Tüketici sinizminin demografik özelliklere göre farklılık gösterip göstermediğini inceleyen Andaç (2019), tüketici sinizminin cinsiyet, yaş, medeni durum, eğitim ve gelir düzeylerine göre anlamlı bir farklılık gösterdiğini ve erkeklerin kadınlara göre daha fazla sinik tutum gösterdiklerini bulmuştur. Göktaş (2019) tarafından gerçekleştirilen benzer bir araştırmada ise tüketici sinizminin cinsiyet açısından anlamlı bir farklııı gösterdiği ve erkek tüketicilerin kadınlara göre daha sinik oldukları bulgusuna ulaşılmıştır. Konuyla ilgili daha kesin değerlendirmeler yapabilmek için, tüketici sinizmini demografik özellikler açısından inceleyen daha fazla araştırmaya ihtiyaç olduğu düşünülmektedir.

Yukarıda açıklandığı üzere sosyal bilimler literatüründe sinizm ile demografik özellikler arasındaki ilişkileri inceleyen araştırmalar bulunmasına rağmen tüketici sinizmini demografik özellikler açısından inceleyen araştırmalar oldukça kısıtıdır. Hizmet sektörüne yönelik tüketici sinizminin tüketicilerin demografik özelliklerine göre farklılık gösterip göstermediği ise henüz araştırılmamıştır. Buradan hareketle, hizmet sektörüne yönelik tüketici sinizminin tüketicilerin demografik özelliklerine göre farklılık gösterip göstermediğini ortaya koymak üzere aşağıdaki hipotezler oluşturulmuştur:

$\boldsymbol{H}_{1}$ : Hizmet sektörüne yönelik tüketici sinizmi cinsiyete göre anlamlı bir farklılık gösterir.

$\boldsymbol{H}_{2}$ : Hizmet sektörüne yönelik tüketici sinizmi medeni duruma göre anlamlı bir farklılık gösterir.

$\boldsymbol{H}_{3}$ : Hizmet sektörüne yönelik tüketici sinizmi yaşa göre anlamlı bir farklılık gösterir.

$\boldsymbol{H}_{4}$ : Hizmet sektörüne yönelik tüketici sinizmi eğitim durumuna göre anlamlı bir farklılık gösterir.

$\boldsymbol{H}_{5}$ : Hizmet sektörüne yönelik tüketici sinizmi gelire göre anlamlı bir farklılık gösterir.

\section{Yöntem}

Araştırmanın amacı, hizmet sektörüne yönelik tüketici sinizminin tüketicilerin demografik özelliklerine göre farklıık gösterip göstermediğini ortaya koymaktır. Araştırmanın ana kütlesini, Bursa ilinde yaşayan ve hizmet satın alan / kullanan tüketiciler oluşturmaktadır. 31 Aralık 2018 tarihi itibariyle, Bursa ilinde 15 yaş ve üzerindeki kişi sayısı 2.339.964'tür. Dolayısıyla araştırmanın ana kütle büyüklüğü 2.339.964 olarak belirlenmiştir. Sekaran (2003: 294)'a göre, ana kütle büyüklüğünün 1.000 .000 ve üzeri olması durumunda, örneklem büyüklüğü en az 384 olmalıdır. Buradan hareketle, 2.339.964 olarak tespit edilen ana kütle büyüklüğü için, \%95 güven düzeyinde $\% 5$ hata payı ile en az 384 anketin araştırma için yeterli olacağı ifade edilebilir.

Araştırmada, süre ve maliyet gibi kısıtlayıcı unsurlar nedeniyle kolayda örnekleme yöntemi kullanılmıştır. Cevaplanma oranını arttırmak ve verilerin doğruluğunu kontrol edebilmek amacıyla yüz yüze anket yöntemi aracılığıyla araştırma verileri toplanmıştır. Anket formundaki soruların anlaşılır olup olmadığını test etmek ve anket formuna son şeklini vermek için, 05-25 Şubat 2019 tarihleri arasında hedef kitlede yer alan 50 kişi üzerinde bir pilot çalışma uygulanmıştır. Pilot çalışma sonucunda, anket formunda herhangi bir değişiklik yapılmamış ve araştırma verileri, 3 Mart - 4 Haziran 2019 tarihleri arasında Bursa ilindeki hizmet satın alan/kullanan tüketicilerden elde edilmiştir. Veri toplama süreci sonucunda, analize uygun 432 ankete ulaşılmış ve verilerin analizinde, IBM SPSS 23 paket programı kullanılmıştır.

Anket formu 2 bölümden oluşmaktadır. Illk bölümde, tüketici sinizmini ölçmek üzere 8 ifadeyi içeren ve Helm vd. (2015) tarafından geliştirilen tüketici sinizmi ölçeği yer almaktadır. 5 dereceli Likert tipi ölçeğin yanıt kategorisi, 1=Kesinlikle Katılmıyorum, 2=Katılmıyorum, 3=Kararsızım, 4=Katılıyorum ve 5=Kesinlikle 
Katılıyorum olarak sıralanmaktadır. i̇kinci bölümde ise araştırma katılımcılarının demografik özelliklerini ortaya koymak üzere 5 kategorik soru bulunmaktadır. Araştırmada kullanılan anket formu için etik kurul onayı, Bursa Uludağ Üniversitesi Sosyal ve Beşeri Bilimler Araştırma ve Yayın Etik Kurulu'ndan alınmıştır (28.09.2018).

\section{Bulgular}

Araştırma hipotezleri test edilmeden önce, araştırmada kullanılan ölçeğin güvenilirlik analizi yapılmış ve araştırma verilerinin normal dağılım gösterip göstermediği incelenmiştir. Daha sonra, araştırma katılımcılarının demografik özelliklerini ortaya koymak üzere frekans analizi uygulanmıştır. Son olarak, bağımsız örneklem t-testi ve tek yönlü varyans analizi (ANOVA) yöntemleri kullanılarak araştırma hipotezleri test edilmiş ve elde edilen bulgular değerlendirilmiştir.

\subsection{Güvenilirlik Analizi ve Normallik Testi Sonuçları}

Araştırmada kullanılan ve 8 ifadeyi içeren tüketici sinizmi ölçeğinin güvenilirlik analizi, Cronbach's Alpha yöntemiyle yapılmıştır. Güvenilirlik analizi sonucunda, araştırma ölçeğinin Cronbach's Alpha katsayısı 0,744 olarak hesaplanmıştır. Bu değer, Cronbach's Alpha için genellikle eşik değer kabul edilen 0,70'in (Hair, Black, Babin ve Anderson, 2014: 123) üzerindedir. Buradan hareketle, araştırmada kullanılan tüketici sinizmi ölçeğinin güvenilir olduğunu ifade etmek mümkündür.

Bağımsız örneklem t-testi ve ANOVA gibi parametrik analiz tekniklerinin kullanılabilmesi için araştırma verilerinin normal dağııı göstermesi gerekmektedir. Verilerin normal dağııma sahip olup olmadıkları, çarpıklık (skewness) ve basıklık (kurtosis) değerleri veya Kolmogorov-Smirnov ve Shapiro-Wilk testleri gibi çeşitli yöntemlerle belirlenebilmektedir. Bu araştırmada, verilerin çarpıklık ve basıklık değerleri hesaplanmıştır. Verilerin normal dağılıma sahip olabilmesi için, 0,05 anlamlılık düzeyi için, çarpıklık ve basıklık değerlerinin $\pm 1,96$ değer aralığında olması gerekmektedir (Hair vd., 2014: 71). Verilerin çarpıklık ve basıkık değerleri hesaplanmış ve elde edilen çarpıklık ve basıklık değerlerinin $\pm 1,96$ değer aralığında olduğu görülmüştür. Dolayısıyla verilerin normal dağılım gösterdiğini ifade etmek mümkündür. Buradan hareketle, araştırma verilerinin analizinde bağımsız örneklem t-testi ve ANOVA teknikleri kullanılmıştır.

\subsection{Frekans Analizi Sonuçları}

Araştırma katılımcılarının demografik özelliklerini ortaya koymak üzere frekans analizi uygulanmıştır. Tablo 1, frekans analizi sonuçlarını göstermektedir.

Tablo 1'de görüldüğü gibi, kadın $(\% 48,4)$ ve erkek $(\% 51,6)$ katılımcıların oranları birbirine oldukça yakındır. Medeni durum açısından bakıldığında, bekâr katılımcıların $(\% 65,7)$ çoğunlukta olduğu ve bunu evli katılımcıların $(\% 34,3)$ izlediği görülmektedir. Katılımcıların yaş grupları incelendiğinde, katıımcıların yarısının 21-30 yaş arasında $(\% 49,8)$ olduğu görülmektedir. Bu yaş aralığındaki katılımcıları ise sırasıyla 31-40 yaş $(\% 27,5), 41-50$ yaş $(\% 10,2), 20$ yaş ve altı $(\% 8,8)$ ve 51 ve üzeri yaş $(\% 3,7)$ arasındaki katılımcılar izlemektedir. Eğitim durumu açısından, katılımcıların çoğunluğunu üniversite mezunları $(\% 60,6)$ oluşturmakta ve bu katılımcıları, sırasıyla yüksek lisans mezunu $(\% 18,8)$, lise mezunu $(\% 12,7)$, doktora mezunu $(\% 6)$ ve ilköğretim mezunu (\%1,9) katılımcılar izlemektedir. Son olarak katılımcıların aylık gelir düzeyleri incelendiğinde, tüm katılımcıların üçte birinin $2000 \mathrm{TL}$ ve altında $(\% 33,3)$ aylık gelire sahip olduğu görülmektedir. Bu gelir grubunu ise sirasiyla 2001 TL-3000 TL (\%18,3), 3001 TL-4000 TL (\%17,4), 4001 TL-5000 TL (\%13,2), 5001 TL-6000 TL (\%9), 7001 TL ve üzeri $(\% 5,1)$ ve 6001 TL-7000 TL $(\% 3,7)$ aylık gelire sahip olan katılımcılar izlemektedir. 
G. Akcay - E. Ozdemir

Tablo 1. Katılımcıların Demografik Özelliklerine İlişkin Frekans Analizi Sonuçları

\begin{tabular}{|c|c|c|c|}
\hline \multicolumn{2}{|c|}{ Demografik Özellikler } & n & $\%$ \\
\hline \multirow{2}{*}{ Cinsiyet } & Kadın & 209 & 48,4 \\
\hline & Erkek & 223 & 51,6 \\
\hline \multirow{2}{*}{ Medeni Durum } & Bekâr & 284 & 65,7 \\
\hline & Evli & 148 & 34,3 \\
\hline \multirow{5}{*}{ Yaş } & 20 ve altı & 38 & 8,8 \\
\hline & $21-30$ & 215 & 49,8 \\
\hline & $31-40$ & 119 & 27,5 \\
\hline & $41-50$ & 44 & 10,2 \\
\hline & 51 ve üzeri & 16 & 3,7 \\
\hline \multirow{5}{*}{ Eğitim Durumu } & İlköğretim Mezunu & 8 & 1,9 \\
\hline & Lise Mezunu & 55 & 12,7 \\
\hline & Üniversite Mezunu & 262 & 60,6 \\
\hline & Yüksek Lisans Mezunu & 81 & 18,8 \\
\hline & Doktora Mezunu & 26 & 6,0 \\
\hline \multirow{7}{*}{ Gelir } & 2000 TL ve altı & 144 & 33,3 \\
\hline & 2001 TL-3000 TL & 79 & 18,3 \\
\hline & 3001 TL-4000 TL & 75 & 17,4 \\
\hline & 4001 TL-5000 TL & 57 & 13,2 \\
\hline & 5001 TL-6000 TL & 39 & 9,0 \\
\hline & 6001 TL-7000 TL & 16 & 3,7 \\
\hline & 7001 TL ve üzeri & 22 & 5,1 \\
\hline \multicolumn{2}{|l|}{ Toplam } & 432 & 100 \\
\hline
\end{tabular}

\subsection{Bağımsız Örneklem t-Testi Sonuçları}

Hizmet sektörüne yönelik tüketici sinizminin, tüketicilerin cinsiyeti ve medeni durumuna göre farklılık gösterip göstermediğini ortaya koymak üzere oluşturulan $\mathrm{H}_{1}$ ve $\mathrm{H}_{2}$ hipotezlerinin test edilmesinde bağımsız örneklem t-testi kullanılmıştır. Tablo 2, cinsiyete göre bağımsız örneklem t-testi sonuçlarını göstermektedir.

Tablo 2. Cinsiyete Göre Bağımsız Örneklem t-Testi Sonuçları

\begin{tabular}{|l|c|c|c|c|c|}
\hline Cinsiyet & $\mathbf{n}$ & $\overline{\mathrm{X}}$ & ss. & $\mathbf{T}$ & $\mathbf{p}$ \\
\cline { 1 - 4 } Kadın & 209 & 3,861 & 0,423 & \multirow{2}{*}{$-1,533$} & \multirow{2}{*}{0,126} \\
\hline Erkek & 223 & 3,922 & 0,408 & \\
\hline
\end{tabular}

Tablo 2'de görüldüğü üzere, 0,126 olarak bulunan $p$ değeri 0,05 'den büyüktür $(p=0,126>0,05)$. Bu bulguya göre, hizmet sektörüne yönelik tüketici sinizmi cinsiyete göre anlamlı bir farklılık göstermemektedir. Dolayısıyla $\mathrm{H}_{1}$ hipotezi desteklenmemiştir.

Tablo 3, medeni duruma göre bağımsız örneklem t-testi sonuçlarını göstermektedir.

Tablo 3. Medeni Duruma Göre Bağımsız Örneklem t-Testi Sonuçları

\begin{tabular}{|l|c|c|c|c|c|}
\hline Medeni Durum & $\mathbf{n}$ & $\overline{\mathrm{X}}$ & $\mathbf{s s .}$ & $\mathbf{T}$ & $\mathbf{p}$ \\
\cline { 1 - 4 } Bekâr & 284 & 3,862 & 0,416 & \multirow{2}{*}{$-2,131$} & \multirow{2}{*}{0,034} \\
\hline Evli & 148 & 3,951 & 0,412 & \\
\hline
\end{tabular}

Tablo 3'de görüldüğü üzere, 0,034 olarak bulunan $p$ değeri 0,05 'den küçüktür $(p=0,034<0,05)$. Bu bulguya göre, hizmet sektörüne yönelik tüketici sinizmi medeni duruma göre anlamlı bir farklılık göstermektedir. Buradan hareketle, $\mathrm{H}_{2}$ hipotezi desteklenmiştir. Hizmet sektörüne yönelik tüketici sinizminin 
medeni duruma göre ortalama değerleri $(\bar{x})$ incelendiğinde, evli katılımcıların tüketici sinizmi puan ortalamasının $(\overline{\mathrm{x}}=3,951)$ bekâr katılımcılardan $(\overline{\mathrm{x}}=3,862)$ yüksek olduğu görülmektedir. Buradan hareketle, hizmet sektörüne yönelik tüketici sinizminin bekâr tüketicilere göre evli tüketicilerde daha fazla görüldüğü ifade edilebilir.

\subsection{Tek Yönlü Varyans Analizi (ANOVA) Sonuçları}

Hizmet sektörüne yönelik tüketici sinizminin, yaş, eğitim durumu ve gelire göre farklılık gösterip göstermediğini ortaya koymak üzere oluşturulan $\mathrm{H}_{3}, \mathrm{H}_{4}$ ve $\mathrm{H}_{5}$ hipotezleri ANOVA tekniğiyle test edilmiştir.

Hizmet sektörüne yönelik tüketici sinizminin yaşa göre farklılık gösterip göstermediğini ortaya koymak üzere ANOVA tekniği uygulanmıştır. Ancak bu analize geçilmeden önce, varyansların homojen dağııp dağılmadığını belirlemek üzere Levene testi yapılmıştır. ANOVA'nın varyansların homojenliği varsayımının sağlanabilmesi için, Levene testinde elde edilen $p$ değerinin 0,05 'den büyük olması gerekmektedir. Tablo 4 , Levene testi sonuçlarını göstermektedir.

Tablo 4. Levene Testi Sonuçları (Yaş)

\begin{tabular}{|c|c|c|c|c|}
\hline & F & df1 & df2 & P \\
\hline Tüketici Sinizmi & 0,264 & 4 & 427 & 0,901 \\
\hline
\end{tabular}

Tablo 4'de görüldüğü üzere, $p=0,901>0,05$ olarak bulunmuştur. Bu sonuç, varyansların homojen dağıldığını göstermektedir. Varyansların homojenliği varsayımının sağlanmasından sonra, ANOVA uygulanmıştır. Tablo 5, yaşa göre ANOVA sonuçlarını göstermektedir.

Tablo 5. Yaşa Göre ANOVA Sonuçları

\begin{tabular}{|c|c|c|c|c|c|c|c|c|c|}
\hline & Yaş & $\mathrm{n}$ & $\bar{x}$ & ss. & $\begin{array}{c}\text { Varyansın } \\
\text { Kaynağı }\end{array}$ & $\begin{array}{c}\text { Kareler } \\
\text { Top. }\end{array}$ & $\begin{array}{c}\text { Kareler } \\
\text { Ort. }\end{array}$ & $\mathbf{F}$ & $\mathbf{P}$ \\
\hline \multirow{5}{*}{$\begin{array}{l}\text { Tüketici } \\
\text { Sinizmi }\end{array}$} & 20 ve altı & 38 & 3,825 & 0,409 & \multirow{2}{*}{ Gruplar arası } & \multirow{2}{*}{1,347} & \multirow{2}{*}{0,337} & \multirow{6}{*}{1,958} & \multirow{6}{*}{0,100} \\
\hline & $21-30$ & 215 & 3,870 & 0,413 & & & & & \\
\hline & $31-40$ & 119 & 3,899 & 0,416 & \multirow{2}{*}{ Gruplar içi } & \multirow{2}{*}{74,451} & \multirow{2}{*}{0,172} & & \\
\hline & $41-50$ & 44 & 3,960 & 0,393 & & & & & \\
\hline & $\begin{array}{l}51 \text { ve } \\
\text { üzeri }\end{array}$ & 16 & 4,125 & 0,480 & \multirow[t]{2}{*}{ Toplam } & \multirow[t]{2}{*}{74,798} & & & \\
\hline \multicolumn{2}{|c|}{ Toplam } & 432 & 3,892 & 0,416 & & & & & \\
\hline
\end{tabular}

Tablo 5'de görüldüğü üzere, hizmet sektörüne yönelik tüketici sinizmi yaşa göre anlamlı bir farklılık göstermemektedir $(F=1,958, p=0,100>0,05)$. Dolayısıyla $\mathrm{H}_{3}$ hipotezi desteklenmemiştir.

Hizmet sektörüne yönelik tüketici sinizminin eğitim durumuna göre anlamlı bir farklılık gösterip göstermediğini belirlemek üzere ANOVA yapılmadan önce, Levene testi uygulanmıştır. Tablo 6 , Levene testi sonuçlarını göstermektedir.

Tablo 6. Levene Testi Sonuçları (Eğitim Durumu)

\begin{tabular}{|l|c|c|c|c|}
\hline & F & df1 & df2 & P \\
\hline Tüketici Sinizmi & 2,340 & 4 & 427 & 0,054 \\
\hline
\end{tabular}

Tablo 6 incelendiğinde, $p=0,054>0,05$ olduğu görülmektedir. Bu sonuç, varyansların homojen dağıldığını ifade etmektedir. Homojenlik varsayımının sağlanmasıyla ANOVA'ya geçilmiştir. Tablo 7, eğitim durumuna göre tek yönlü varyans analizi (ANOVA) sonuçlarını göstermektedir. 
Tablo 7. Eğitim Durumuna Göre ANOVA Sonuçları

\begin{tabular}{|c|c|c|c|c|c|c|c|c|c|}
\hline & $\begin{array}{l}\text { Eğitim } \\
\text { Durumu }\end{array}$ & $\mathbf{n}$ & $\overline{\mathrm{X}}$ & ss. & $\begin{array}{c}\text { Varyansın } \\
\text { Kaynağı }\end{array}$ & $\begin{array}{c}\text { Kareler } \\
\text { Top. }\end{array}$ & $\begin{array}{c}\text { Kareler } \\
\text { Ort. }\end{array}$ & $\mathbf{F}$ & $\mathbf{P}$ \\
\hline \multirow{5}{*}{$\begin{array}{l}\text { Tüketic } \\
\text { Sinizmi }\end{array}$} & ilköğretim & 8 & 4,031 & 0,431 & \multirow{2}{*}{ Gruplar arası } & \multirow{2}{*}{0,633} & \multirow{2}{*}{0,158} & \multirow{6}{*}{0,912} & \multirow{6}{*}{0,457} \\
\hline & Lise & 55 & 3,879 & 0,442 & & & & & \\
\hline & Üniversite & 262 & 3,913 & 0,429 & \multirow{2}{*}{ Gruplar içi } & \multirow{2}{*}{74,165} & \multirow{2}{*}{0,174} & & \\
\hline & Yüksek Lisans & 81 & 3,850 & 0,386 & & & & & \\
\hline & Doktora & 26 & 3,802 & 0,294 & \multirow{2}{*}{ Toplam } & \multirow{2}{*}{74,798} & & & \\
\hline & Toplam & 432 & 3,892 & 0,416 & & & & & \\
\hline
\end{tabular}

Tablo 7'de görüldüğü üzere, hizmet sektörüne yönelik tüketici sinizmi eğitim durumuna göre anlamlı bir farklılık göstermemektedir ( $F=0,912, p=0,457>0,05)$. Dolayısıyla $\mathrm{H}_{4}$ hipotezi desteklenmemiştir.

Hizmet sektörüne yönelik tüketici sinizminin gelire göre anlamlı bir farklılık gösterip göstermediğini ortaya koymak için ANOVA yapılmadan önce, Levene testi uygulanmıştır._Tablo 8, Levene testi sonuçlarını göstermektedir.

Tablo 8. Levene Testi Sonuçları (Gelir)

\begin{tabular}{|l|c|c|c|c|}
\hline & $\mathbf{F}$ & df1 & df2 & p \\
\hline Tüketici Sinizmi & 0,749 & 6 & 425 & 0,611 \\
\hline
\end{tabular}

Tablo 8'de, p=0,611>0,05 olduğu görülmektedir. Buradan hareketle, homojenlik varsayımının sağlandığı ifade edilebilir. Bu aşamadan sonra, hizmet sektörüne yönelik tüketici sinizminin gelire göre anlamlı bir farklılık gösterip göstermediğini belirlemek üzere ANOVA yapılmıştır. Tablo 9, gelire göre ANOVA sonuçlarını göstermektedir.

Tablo 9. Gelire Göre ANOVA Sonuçları

\begin{tabular}{|c|c|c|c|c|c|c|c|c|c|}
\hline & Gelir & $\mathrm{n}$ & $\overline{\mathrm{x}}$ & ss. & $\begin{array}{c}\text { Varyansın } \\
\text { Kaynağı }\end{array}$ & $\begin{array}{c}\text { Kareler } \\
\text { Top. }\end{array}$ & $\begin{array}{c}\text { Kareler } \\
\text { Ort. }\end{array}$ & $\mathbf{F}$ & p \\
\hline \multirow{7}{*}{$\begin{array}{l}\text { Tüketic } \\
\text { Sinizmi }\end{array}$} & $2000 \mathrm{TL}$ ve altı & 144 & 3,828 & 0,434 & \multirow{2}{*}{ Gruplar arası } & \multirow{2}{*}{1,363} & \multirow{2}{*}{0,227} & \multirow{8}{*}{1,315} & \multirow{8}{*}{0,249} \\
\hline & $2001-3000 \mathrm{TL}$ & 79 & 3,890 & 0,425 & & & & & \\
\hline & 3001-4000 TL & 75 & 3,945 & 0,381 & \multirow{2}{*}{ Gruplar içi } & \multirow{2}{*}{74,436} & \multirow{2}{*}{0,173} & & \\
\hline & 4001-5000 TL & 57 & 3,932 & 0,410 & & & & & \\
\hline & 5001-6000 TL & 39 & 3,878 & 0,380 & \multirow{4}{*}{ Toplam } & \multirow{4}{*}{74,798} & & & \\
\hline & $6001-7000 \mathrm{TL}$ & 16 & 4,039 & 0,383 & & & & & \\
\hline & 7001 TL ve üzeri & 22 & 3,965 & 0,458 & & & & & \\
\hline & Toplam & 432 & 3,892 & 0,416 & & & & & \\
\hline
\end{tabular}

Tablo 9'da görüldüğü üzere, hizmet sektörüne yönelik tüketici sinizmi gelire göre anlamlı bir farklılık göstermemektedir $(F=1,315, p=0,249>0,05)$. Dolayısıyla $H_{5}$ hipotezi desteklenmemiştir.

Bağımsız örneklem t-testi ve ANOVA uygulanarak araştırma hipotezleri test edildikten sonra, Tablo 10 'da hipotezlerin desteklenme/desteklenmeme durumları özet olarak sunulmaktadır. 
Tablo 10. Araştırma Hipotezlerinin Desteklenme/Desteklenmeme Durumları

\begin{tabular}{|l|c|}
\hline \multicolumn{1}{|c|}{ Araştırma Hipotezleri } & \multicolumn{1}{|c|}{ Sonuç } \\
\hline $\begin{array}{l}\mathbf{H}_{1}: \text { Hizmet sektörüne yönelik tüketici sinizmi cinsiyete göre anlamlı bir farklılık } \\
\text { gösterir. }\end{array}$ & Desteklenmedi \\
\hline $\begin{array}{l}\mathbf{H}_{2}: \text { Hizmet sektörüne yönelik tüketici sinizmi medeni duruma göre anlamlı bir farklılık } \\
\text { gösterir. }\end{array}$ & Desteklendi \\
\hline $\mathbf{H}_{3}$ : Hizmet sektörüne yönelik tüketici sinizmi yaşa göre anlamlı bir farklılık gösterir. & Desteklenmedi \\
\hline $\begin{array}{l}\mathbf{H}_{4}: \text { Hizmet sektörüne yönelik tüketici sinizmi eğitim durumuna göre anlamlı bir } \\
\text { farklılık gösterir. }\end{array}$ & Desteklenmedi \\
\hline $\mathbf{H}_{5}:$ Hizmet sektörüne yönelik tüketici sinizmi gelire göre anlamlı bir farklılık gösterir. & Desteklenmedi \\
\hline
\end{tabular}

Tablo 10'da görüldüğü üzere, hizmet sektörüne yönelik tüketici sinizmi medeni duruma göre anlamlı bir farklılık gösterirken, cinsiyet, yaş, eğitim durumu ve gelire göre anlamlı bir farklılık göstermemektedir.

\section{Sonuç ve Öneriler}

Bu çalışmada, hizmet sektörüne yönelik tüketici sinizminin demografik özelliklere göre farklılık gösterip göstermediği araştırılmış ve hizmet sektörüne yönelik tüketici sinizminin medeni duruma göre anlamlı bir farklılık gösterdiği bulunmuştur. Konuyla ilgili çalışmalar incelendiğinde, bu çalışmayla benzer olarak, Andaç (2019)'ın tüketici sinizminin medeni durum açısından anlamlı bir fark gösterdiği bulgusuna ulaştığı ancak ilgili çalışmada, bu çalışmadan farklı olarak tüketici sinizminin pazara ve pazardaki işletmelere karşı geliştirilen genel bir tutum olarak incelendiği görülmektedir. Dolayısıyla bu çalışmanın medeni duruma ilişkin bulgusunun, tüketici sinizminin hedefindeki unsur (hizmet sektörü) açısından Andaç (2019)'ın çalışmasından ayrıldığı ifade edilebilir. Bu çalışmada, evli tüketicilerin bekâr tüketicilere göre hizmet sektörüne karşı daha fazla sinik tutum geliştirdikleri bulunmuştur. Bu sonucun ortaya çıkmasında, çeşitli faktörlerin etkili olabileceği düşünülmektedir. Örneğin evli tüketicilerin kendi ihtiyaçları ile ailedeki diğer üyelerin (eş ve çocuklar) ihtiyaçları farklılık göstermekte ve evli tüketiciler, gerek kendi ihtiyaçları gerekse diğer aile üyelerinin ihtiyaçlarına uygun çözümler bulmak amacıyla, bekâr tüketicilere göre, daha fazla hizmet satın almakta veya hizmet işletmeleriyle daha fazla değişim ilişkisinde bulunmaktadırlar. Bu durumun, evli tüketicilerin gerek bireysel gerekse diğer aile üyeleri yoluyla daha fazla olumsuz hizmet deneyimine maruz kalmasına yol açarak, hizmet işletmelerine karşı sinik tutum geliştirme olasılıklarını arttırabileceği düşünülmektedir. Diğer taraftan, Akçay (2021) tarafından gerçekleştirilen çalışmada, hizmet sektörüne karşı geliştirilen sinik tutumun toplumsal/kurumsal sinizmden (topluma ve toplumsal kurumlara karşı gelişen sinizm türü) etkilendiği bulunmuş ve toplumsal açıdan sinik bireylerin mevcut sinik tutumlarını hizmet sektörü gibi farklı bir unsura kolayca aktarmalarının mümkün olduğu ifade edilmiştir. Özellikle Türk toplumu gibi geleneksel değer ve normlara oldukça bağlı olan toplumlarda, evliliğin bireye yüklediği sorumluluk ve kısıtlamaların modern batı toplumlarına göre oldukça fazla olması, bireyin evlilik ve aile kurumları yoluyla toplum ve toplumsal kurumlara karşı sinik tutum geliştirmesine yol açabilir. Bu açıdan, evli bireylerin toplumsal/kurumsal sinizm düzeylerinin bekâr bireylerden daha yüksek olabileceği ve bu durumun, hizmet sektörüne yönelik sinik tutumun gelişimini etkileyebileceği düşünülmektedir. Ancak bu konuda daha kesin değerlendirmeler yapabilmek için, daha fazla araştırmaya ihtiyaç vardır.

Araştırma sonucunda, hizmet sektörüne yönelik tüketici sinizminin cinsiyet, yaş, eğitim durumu ve gelire göre anlamlı bir farklılık göstermediği bulunmuştur. Bu sonucun ortaya çıkmasında, tüketici sinizminin ilgili demografik özelliklerden ziyade tüketicilerin hizmet deneyimlerine ilişkin karşılanmamış beklenti ve değerleri (Chylinski ve Chu, 2010) veya kişilik özellikleri (Helm, 2006) gibi çeşitli faktörlerden etkilenmesinin etkili olabileceği düşünülmektedir. Konuyla ilgili literatür incelendiğinde, tüketici sinizmini cinsiyet, yaş, eğitim durumu ve gelir açısından araştıran çalışmaların farklı sonuçlara ulaştıkları görülmektedir. Indibara'nın (2017) çalışması sonucunda, tüketici sinizminin cinsiyet, yaş ve eğitim durumuna göre anlamlı bir farklılık göstermediği bulunmuştur. Dolayısıyla ilgili çalışmanın bulguları, bu çalışmada elde edilen bulguları destekler niteliktedir. Andaç'ın (2019) çalışmasında, tüketici sinizminin cinsiyet, yaş, eğitim durumu ve gelir açısından, Göktaş'ın (2019) çalışmasında ise tüketici sinizminin cinsiyet açısından anlamlı bir farklılık gösterdiği 
bulunmuştur. Dolayısıyla ilgili çalışmaların bulguları, bu çalışmada elde edilen bulgulardan farklılık göstermektedir. Tüketici sinizmine ilişkin çalışmaların özellikle Türkiye'de oldukça az sayıda olması, bu çalışmada elde edilen bulguların ulusal alan yazında yer alan çalışmalarla karşılaştırılarak değerlendirilmesini ve yorumlanmasını güçleştirmektedir. Bu bağlamda, konuyla ilgili ampirik kanıtlar sunan daha fazla çalışmaya ihtiyaç olduğu açıktır.

\subsection{Araştırmanın Teorik ve Yönetim Açısından Katkıları}

Tüketici sinizminin pazarlama alanı için nispeten yeni bir konu olması nedeniyle, özellikle Türkiye'de, tüketici sinizmine ilişkin çalışma sayısı oldukça kısıtıdır. Illgili çalışmalarda, tüketici sinizmi sıklıkla pazara yönelik genel bir tutum olarak incelenmiş, hizmet sektörü açısından ele alınmamıştır. Tüketici sinizmi tüketicilerin demografik özellikleri açısından ise henüz yeterince araştırılmamıştır. Dolayısıyla hizmet sektörüne yönelik tüketici sinizmini demografik özellikler açısından inceleyen ve medeni duruma göre hizmet sektörüne yönelik tüketici sinizminin anlamlı bir farklılık gösterdiği bulgusuna ulaşan bu çalışmanın, pazarlama literatürüne katkı sağladığı düşünülmektedir.

Bu çalışmada, tüketici sinizminin kavramsal alt yapısının yanı sıra tüketici sinizmine ilişkin geniş bir literatür incelemesine yer verilmiştir. Sunulan teorik çerçevenin, işletmeler açısından pek çok olumsuz sonucu beraberinde getiren tüketici sinizmi konusunda hizmet işletmelerinin bilinçlendirilmesini sağlamak açısından önemli olduğu düşünülmektedir. Diğer taraftan bu çalışma sonucunda, hizmet sektörüne yönelik tüketici sinizminin medeni duruma göre farklılık gösterirken, cinsiyet, yaş, eğitim durumu ve gelire göre farklılık göstermediği bulunmuştur. Bu sonuç, hizmet işletmelerinin tüketici sinizmine yönelik stratejilerini planlarken tüketicilerin demografik özelliklerini göz ardı etmemeleri gerektiğini göstermesi açısından önemlidir. Dolayısıyla bu çalışmanın, hizmet işletmelerinin tüketici sinizmini önleme ve sinik tüketicilerle başa çıkma çabalarına katkı sağlayacağı düşünülmektedir. Ayrıca bu çalışmada, hizmet işletmelerine aşağıda yer alan öneriler sunulmuştur. Sunulan önerilerin, hizmet işletmelerinin tüketici sinizmini etkin bir şekilde yönetme ve müşteri memnuniyeti ve sadakati sağlama çabalarına destek olması beklenmektedir.

$\mathrm{Bu}$ araştırmanın sonuçları, tüketici sinizminin tüketicilerin medeni durumundan etkilendiğini göstermektedir. Bu açıdan hizmet işletmelerine, pazar bölümlendirme faaliyetlerinde, hizmetin tasarım ve üretim sürecinde ve tutundurma ve satış çabalarında tüketicilerin medeni durumlarını göz ardı etmemeleri ve evli tüketicilere yönelik farklı stratejiler geliştirmeleri önerilmektedir. Ayrıca hizmet işletmelerinin, evli tüketicilerde sinik tutumun gelişimini önlemeye ve mevcut sinizmi tersine çevirmeye yönelik stratejilerini genç ve yeni evli çiftler, evli ve çocuklu çiftler, çocukları evden ayrılmış evli çiftler gibi aşamaları içeren aile yaşam döngüsüne (Schiffman ve Wisenblit, 2015: 269) göre planlamaları da etkili bir strateji olabilir. Örneğin evli ve çocuklu tüketiciler için kendi ihtiyaçlarından ziyade çocuklarının ihtiyaçlarını karşılamak daha ön plandadır. Dolayısıyla bu tüketicilere yönelik hizmetler sunan işletmelere, hizmet sürecinde çocukların güvenliği için tehdit oluşturan her türlü unsuru ortadan kaldırmaları, sağlığa zararlı hizmetleri üretmekten, hizmet çalışanlarının bilgi ve tecrübesi konusunda ebeveynleri eksik veya yanlış bilgilendirmekten, çocukların fiziksel ve ruhsal gelişimini olumsuz yönde etkileyen reklamlar sunmaktan vb. kaçınmaları önerilmektedir.

Evli çiftlere yönelik hizmetler sunan işletmelere, hizmetin soyut yapısının olumsuz etkilerini azaltmak için reklamlarda somut unsurlara ağırlık verilmesi, hizmetin satış sürecinde müşteriye baskı uygulamak, müşteriyi yanlış bilgilendirmek ve müşteriler arasında ayrımcılık yapmak gibi etik dışı uygulamalardan şiddetle kaçınılması önerilmektedir. Zira bu stratejilerin, sinizmin önlenmesi ve sinik tüketicilerin işletmenin dürüst ve güvenilir olduğuna ikna edilmesi açısından hizmet işletmelerine faydalı olabileceği düşünülmektedir. Diğer taraftan, restoran, kafeterya ve otel gibi hizmet işletmelerinin, evli ve özellikle çocuklu tüketiciler için fiziksel ve psikolojik açıdan en uygun hizmet ortamını yaratmaları, anneler için emzirme odaları ve çocuklar için spor ve oyun alanları tahsis etmeleri de evli tüketicilerin sinik tutum geliştirmelerini önlemek açısından faydalı olabilir.

Son olarak, hizmetin performans ve kalitesinin arttırılması, tüketicilere hizmet satışı sonrasında gereken desteğin sağlanması ve sinik tüketicilere yönelik etkili iletişim ve satış taktikleri konusunda hizmet 
çalışanlarının eğitilmesi sinizmi önleme ve mevcut sinizmle başa çıkmada hizmet işletmelerine destek olabileceği düşünülen diğer önerilerdir.

\subsection{Araştırmanın Kısıtları ve Gelecekteki Araştırmacılara Öneriler}

$\mathrm{Bu}$ araştırma, Bursa ilinde ve hizmet satın alan/kullanan tüketiciler üzerinde gerçekleştirilmiştir. Gelecekteki araştırmaların, farkı şehir veya ülkelerde, farklı özelliklere sahip bir hedef kitle veya daha geniş bir örneklem grubu üzerinde gerçekleştirilmesi durumunda elde edilen sonuçların farklılık gösterebileceği düşünülmektedir. Dolayısıyla gelecekteki araştırmaların, coğrafi alan, hedef kitle ve örneklem büyüklüğü açısından farklılaştırılması önerilmektedir. Diğer taraftan, araştırmada tesadüfi olmayan örnekleme yöntemlerinden kolayda örnekleme yöntemi kullanılmıştır. Bu açıdan, gelecekteki araştırmalarda tesadüfi örnekleme yöntemlerinin tercih edilmesi öneri olarak sunulabilir.

Bu araştırmada, tüketici sinizmi cinsiyet, medeni durum, yaş, eğitim durumu ve gelir açısından araştırılmıştır. Gelecekteki araştırmalarda, bu araştırmadan farklı olarak, hizmet sektörüne yönelik tüketici sinizminin meslek, etnik köken ve aile yaşam döngüsü gibi farklı demografik faktörler açısından veya birkaç demografik faktör bir arada ele alınarak incelenmesi önerilmektedir. Diğer taraftan, hizmet sektörü bu araştırmada pek çok alt sektörü / hizmet kolunu içeren ana bir sektör olarak değerlendirilmektedir. Gelecekteki araştırmaların kapsamı, eğitim, sağlık, turizm, ulaştırma, haberleşme ve eğlence gibi belirli bir alt sektör / hizmet kolu seçilerek daraltılabilir. Zira bu yönde yapılacak araştırmaların, ilgili sektörlerde faaliyet gösteren hizmet işletmelerine fayda sağlayabileceği düşünülmektedir. Ayrıca, tüketici sinizminin hizmet sektörü dışındaki diğer sektörlere, ürün kategorilerine veya belirli markalara yönelik olarak araştırılması da gelecekte yapılacak araştırmalara öneri olarak sunulabilir.

Bu araştırmada, hizmet sektörüne yönelik tüketici sinizminin demografik özellikler açısından farklııı gösterip göstermediği araştırılmıştır. Ancak hizmet sektörüne yönelik sinik tutumun gelişimini öngörebilmek açısından demografik özellikler dışındaki faktörlerin de incelenmesi gerektiği düşünülmektedir. Zira tüketici sinizmi literatürü incelendiğinde, tüketici sinizminin gelişimi üzerinde kişilik özelliklerinin (Helm, 2006), yaşanan / tanık olunan belirli an veya olayların (Helm, 2004, 2006), amaç ve değer uyuşmazlıklarının (Chylinski ve Chu, 2010) ve etik dışı pazarlama uygulamalarının (Akçay, 2021) etkili olduğu görülmektedir. Dolayısıyla gelecekte yapılacak araştırmalarda, demografik özelliklerin tüketici sinizminin gelişiminde etkili olduğu düşünülen diğer unsurlarla birlikte araştırılması öneri olarak sunulabilir.

\section{Beyan ve Açıklamalar (Declarations and Disclosures)}

Yazarların Etik Sorumlulukları (Ethical Responsibilities of Authors): Bu çalışmanın yazarları, araştırma ve yayın etiği ilkelerine uyduklarını kabul etmektedirler.

Etik Kurul Onayı (Ethical Approval): Araştırmada kullanılan anket formu için etik kurul onayı, Bursa Uludağ Üniversitesi Sosyal ve Beşeri Bilimler Araştırma ve Yayın Etik Kurulu'ndan alınmıştır (28.09.2018)

Çıkar Çatışması (Conflicts of Interest): Yazarlar tarafından herhangi bir çıkar çatışması beyan edilmemiştir.

Finansal Destek (Funding): Yazarlar, çalışmanın hazırlanması ve/veya yayınlanması sürecinde herhangi bir finansal destek almamışlardır.

Yazar Katkı Oranı (Author Contributions): Yazarlar, çalışmaya olan katkılarını şu şekilde beyan etmişlerdir: Kavramlaştırma ve çalışma dizaynı, G. Akçay ve E. Özdemir; verilerin toplanması, G. Akçay; verilerin analizi ve sonuçların yorumlanması, G. Akçay; çalışmanın ilk/taslak halinin yazılması, G. Akçay; çalışmanın gözden geçirilmesi ve düzenlenmesi/düzeltilmesi, G. Akçay ve E. Özdemir. Çalışmanın ilk ve son hali tüm yazarlar tarafından okunmuş ve onaylanmış olup, yazarlar çalışmalarıyla ilgili sorumluluğu kabul etmektedirler.

intihal Denetimi (Plagiarism Checking): Bu çalışma, intihal tarama programı kullanılarak intihal taramasından geçirilmiştir.

ilave Açıklama (Additional Disclosure): Bu çalışmada, Prof. Dr. Erkan Özdemir'in danışmanlı̆ı̆nda Gamze Akçay tarafından 2021 yılında tamamlanan "Tüketici Sinizminin Öncülleri ve Sonuçları: Hizmet Sektörü Üzerinde Bir Araştırma" başlıkı doktora tezinin anket verileri kullanılmıştır. 


\section{Kaynaklar}

Akçay, G. (2021). Tüketici sinizminin öncülleri ve sonuçları: Hizmet sektörü üzerinde bir araştırma. Bursa Uludağ Üniversitesi, Sosyal Bilimler Enstitüsü, Yayımlanmamış Doktora Tezi, Bursa.

Akçay, G., \& Özdemir, E. (2019). Bazen aldatılmış hissine kapılıyor muyuz? Tüketici sinizmi ve sinik tüketici davranışları. (Ed.) R. Altunışık, Tüketimin 1001 bali (ss. 221-237). İstanbul: Beta Yayıncılık.

Andaç, R. E. (2019). Sinizm ve tüketici sinizmi: İstanbul ilinde bir uygulama. İzmir Kâtip Çelebi Üniversitesi, Sosyal Bilimler Enstitüsü, Yayımlanmamış Yüksek Lisans Tezi, İzmir.

Andersson, L. M. (1996). Employee cynicism: An examination using a contract violation framework. Human Relations, 49(11), 1395-1418.

Atılgan, K. Ö., İnce, T., \& Yılmaz, S. (2017). Tüketicilerin satın alma niyetleri ve boykota yönelik tutumlarının tüketici sinizmi, fiyat şeffaflı̆̆ı ve fiyat adaleti bağlamında incelenmesi. Çukurova Üniversitesi Sosyal Bilimler Enstitüsü Dergisi, 26(3), 34-44.

Barefoot, J. C., Dodge, K. A., Peterson, B. L., Dahlstrom, W. G., \& Williams, R. B. (1989). The Cook-Medley hostility scale: Item content and ability to predict survival. Psychosomatic Medicine, 51(1), 46-57.

Chaloupka, W. (1999). Everybody knows: Cynicism in America. Minneapolis: University of Minnesota Press.

Chiaburu, D. S., Peng, A. C., Oh, I. S., Banks, G. C., \& Lomeli, L. C. (2013). Antecedents and consequences of employee organizational cynicism: A meta-analysis. Journal of Vocational Behavior, 83(2), 181-197.

Chu, A., \& Chylinski, M. (2006). A model of consumer cynicism: Antecedents and consequences. Proceedings of the Australian and New Zealand Marketing Academy, 1-8.

Chylinski, M., \& Chu, A. (2010). Consumer cynicism: Antecedents and consequences. European Journal of Marketing, 44(6), 796-837.

Cook, W. W., \& Medley, D. M. (1954). Proposed hostility and parasaic virtue scales for the MMPI. Journal of Applied Psychology, 38(6), 414-418.

Dean, J. W. Jr., Brandes, P., \& Dharwadkar, R. (1998). Organizational cynicism. Academy of Management Review, 23(2), 341-352.

Dekker, H., \& Meijerink, F. (2012). Political cynicism: Conceptualization, operationalization, and explanation. Politics, Culture and Society, 3(1/2), 33-48.

Durand, R. M., \& Lambert, Z. V. (1980). Consumer alienation and support for advertising regulations. Current Issues and Research in Advertising, 3(1), 183-199.

Durand, R. M., \& Lambert, Z. V. (1985). Alienation and criticisms of advertising. Journal of Advertising, 14(3), 9-17.

Durrah, O., Chaudhary, M., \& Gharib, M. (2019). Organizational cynicism and its impact on organizational pride in industrial organizations. International Journal of Environmental Research and Public Health, 16(7), 1-16.

Garner, S. J. (1986). Perceived risk and information sources in services purchasing. The Mid-Atlantic Journal of Business, 24(2), 49-58.

George, W. R., Weinberger, M. G., \& Kelly, J. P. (1985). Consumer risk perceptions: Managerial tool for the service encounter. (Ed.) J. A. Czepiel, M.R. Solomon \& C. F. Surprenant, The service encounter: Managing employee/customer interaction in service businesses (ss.83-100). Lexington (MA): Lexington Books.

Gillani, A., Yousafzai, S., Pallister, J. G., \& Yani-De-Soriano, M. M. (2011). Consumer cynicism: An emergent phenomenon in fairtrade? Academy of Marketing Conference: Marketing Fields Forever, Liverpool, 5-7 July, 1-7.

Göktaş, B. (2019). Tüketici sinizmi kavramı ve ağızdan ağıza pazarlama eylemlerinin sinik tüketici davranışlarına etkisi konusunda bir uygulama. OPUS - Uluslararası Toplum Araştırmaları Dergisi, 13(19), 1650-1692.

Greenglass, E. R., \& Julkunen, J. (1989). Construct validity and sex differences in Cook-Medley hostility. Personality and Individual Differences, 10(2), 209-218.

Guastello, S. J., Rieke, M. L., Guastello, D. D., \& Billings, S. W. (1992). A study of cynicism, personality, and work values. Journal of Psychology, 126(1), 37-48.

Hair, J. F., Black, W. C., Babin, B. J., \& Anderson, R. E. (2014). Multivariate data analysis, 7th Ed., Essex: Pearson Education Limited.

Helm, A. E. (2004). Cynics and skeptics: Consumer dispositional trust. Advances in Consumer Research, 31, $345-351$.

Helm, A. E. (2006). Cynical consumers: Dangerous enemies, loyal friends. University of Missouri, The Graduate School University of Missouri, Unpublished Doctoral Dissertation, Columbia. 
Helm, A. E, Moulard, J. G., \& Richins, M. (2015). Consumer cynicism: Developing a scale to measure underlying attitudes influencing marketplace shaping and withdrawal behaviours. International Journal of Consumer Studies, 39(5), 515-524.

Higgie, R. (2014). Kynical dogs and cynical masters: Contemporary satire, politics and truth-telling. Humor: International Journal of Humor Research, 27(2), 183-201.

Hoffmann, C. P., Lutz, C., \& Ranzini, G. (2016). Privacy cynicism: A new approach to the privacy paradox. Cyberpsychology: Journal of Psychosocial Research on Cyberspace, 10(4), 1-18.

Indibara, I. (2017). Impact of ad-skepticism on consumer cynicism. Parikalpana - KIIT Journal of Management, 13(1), 83-100.

Indibara, I., \& Varshney S. (2020). Cynical consumer: How social cynicism impacts consumer attitude. Journal of Consumer Marketing, 38(1), 78-90.

James, M. S. L. (2005). Antecedents and consequences of cynicism in organizations: An examination of the potential positive and negative effects on school systems. The Florida State University College of Business, Unpublished Doctoral Dissertation, Florida.

Kalağan, G., \& Güzeller, C. O. (2010). Öğretmenlerin örgütsel sinizm düzeylerinin incelenmesi. Pamukkale Üniversitesi Eğitim Fakültesi Dergisi, 27, 83-97.

Kanter, D. L., \& Mirvis, P. H. (1989). The cynical Americans: Living and working in an age of discontent and disillusion (1st Ed.). San Francisco: Jossey-Bass.

Kasalak, G. (2019). The relations between student cynicism and students' life satisfaction. International Journal of Contemporary Educational Research, 6(2), 325-337.

Kudriavtseva, V., \& Tsiplakova, Y. (2017). Tradition of cynicism: From origin to nowadays. IJASOS- International E-Journal of Advances in Social Sciences, 3(9), 918-922.

Lambert, Z. V. (1980). Consumer alienation, general dissatisfaction, and consumerism issues: Conceptual and managerial perspectives. Journal of Retailing, 56(2), 3-24.

Leung, K., Li, F., \& Zhou, F. (2012). Sex differences in social cynicism across societies: The role of men's higher competitiveness and male dominance. Journal of Cross-Cultural Psychology, 43(7), 1152-1166.

Li, F., \& Leung, K. (2011). Effects of evaluation of societal conditions and work-family conflict on social cynicism and distress: A longitudinal analysis. Journal of Applied Social Psychology, 42(3), 717-734.

Luck, G. (2011). Köpeklerin bilgeliği: Antikçağ kiniklerinden metinler (1. Baskı). (çev. O. Özügül) İstanbul: Say Yayınları.

Mazella, D. (2007). The making of modern cynicism (1st Ed.). Charlottesville: University of Virginia Press.

Mikkonen, I., Moisander, J., \& Firat, A. F. (2011) Cynical identity projects as consumer resistance - The scrooge as a social critic? Consumption Markets \& Culture, 14(1), 99-116.

Miller, A. H. (1974). Political issues and trust in government: 1964-1970. American Political Science Review, 68(3), 951972.

Mirvis, P. H., \& Kanter, D. L. (1991). Beyond demography: A psychographic profile of the workforce. Human Resource Management, 30(1), 45-68.

Mitchell, V.W. \& Greatorex, M. (1993). Risk perception and reduction in the purchase of consumer services. The Service Industry Journal, 13(4), 179-200.

Mohr, L. A., Eroglu, D., \& Ellen, P. S. (1998). The development and testing of a measure of skepticism toward environment claims in the marketers' communications. The Journal of Consumers Affairs, 32(1), 1998, 30-55.

Navia, L. E. (1996). Classical cynicism: A critical study (1st Ed.). London: Grennwood Press.

Odou, P., \& Pechpeyrou, P. (2011). Consumer cynicism: From resistance to anti-consumption in a disenchanted world? European Journal of Marketing, 45(11/12), 1799-1808.

Pinkleton, B. E., Austin, E. W., \& Fortman, K. K. J. (1998). Relationships of media use and political disaffection to political efficacy and voting behavior. Journal of Broadcasting and Electronic Media , 42(1), 34-49.

Schiffman, L. G., \& Wisenblit, J. L. (2015). Consumer behavior (11th Ed.) USA: Pearson Education.

Sekaran, U. (2003). Research methods for business: A skill building approach (4th Ed.). New York, John Wiley \& Sons, Inc.

Wanous, J. P., Reichers, A. E., \& Austin, J. T. (1994). Organizational cynicism: An initial study. Academy of Management Best Papers Proceedings, (1), 269-273. 